\title{
多目的遺伝的アルゴリズムを用いたエネルギー消費と経済性 に関する熱源最適計画 \\ MULTI-OBJECTIVE GENETIC ALGORITHM OPTIMIZED FOR ENERGY CONSUMPTION AND COST IN BUILDING ENERGY SYSTEM DESIGN
}

\author{
加用 現 空*, 大岡 龍 三** \\ Genku KAYO and Ryozo OOKA
}

\begin{abstract}
Distributed energy systems based on cogeneration systems afford excellent energy saving potential through the effective use of waste heat from power generators. However, unless an appropriate combination of machinery and operation are used, the expected performance is not achieved, but it is quite difficult to determine the optimal combination of machinery and operation. The authors had already developed and proposed a new optimal design method for building energy systems or distributed energy systems using genetic algorithms (GA) in some previous studies (e.g. Ooka, R. et al., 2008). GAs are able to handle nonlinear optimization problems. The proposed method designs the most efficient energy system by optimizing operation of available systems with consideration for the optimal machinery capacity in the systems. However, it is only intended to optimize primary energy consumption. In practical applications, it is necessary that the method is able to search for optimal energy systems based on various objectives, such as environmental impact factors, economic factors, building structure factors, and so on. Therefore, the method was improved in this study to enable examination of energy systems with various objectives using Multi-Objective Genetic Algorithms (MOGA). This study developed the optimal design method for energy systems in a single building as the first step, with the aim of establishing the optimal design method for a distributed energy system. A case study involving a hospital building was carried out to examine the application potential of the method as the optimal design tool.
\end{abstract}

Keywords : Distributed Energy System, Optimal Design Method, Multi-Objective Genetic Algorithm 分散エネルギーシステム, 最適計画手法, 多目的遺伝的アルゴリズム

1. はじめに

筆者らは既報 1)において、遺伝的アルゴリズム（Genetic Algorithm；GA）を用いた建物エネルギーシステム最適化モデルを 構築した。本モデルは、段階的な開発過程を経て、複数の建物群で 構成される分散エネルギーシステム最適計画への適用を目指す。エ ネルギーシステム計画においては、専門技術者の経験的意思決定に 基づいて行われる場合が一般的であるが、インバータ制御等、近年 の高度な運転制御技術の発達により非線形な入出力特性を持つ機器 が増えつつある状況においては、最適計画の実現や定量的な評価が 困難となる。熱源システムを構成する機器の性能が十分に発揮され るためには、複雑な機器運用が考慮された計画案を定量的に評価で きる設計手法の確立が求められる。既報のモデルは、GA を用い、 機器選定最適化および最適運用計画を導くものであるが、年間一次 エネルギー消費量最小化を目的関数とする単目的最適化に取組むも のであった。設計実務における本モデルの適用を見据え、最適解群 の中から現実解を導く設計手法が必要であると考え、多目的最適化 を可能とするモデルを開発するに至った。本研究では、複数の目的
関数に対し、最適解候補を求めるエネルギーシステム最適化モデル を開発し、ケーススタディを通じてその有効性および設計過程への 適用可能性を検証した。

\section{2. 多目的最適化}

一般に、設計行為は様々な検討要素の組合せと評価の観点が存在 するため、必然的に多目的最適化問題となる。特に、エネルギーシ ステム設計におけるエネルギー消費と経済性の関係は、一方を最小 化するともう一方が増大するトレードオフの関係となることが予想 される。この場合、ただ一つの最適解というものは存在せず、数学 的に等価なパレート解集合が最適解の候補となる。

多目的最適化手法を設計過程一応用寸る試みには、弥田ら 2)、宗 本ら ${ }^{3)}$ の独立住宅設計時の建材・工法選択に適用した研究事例があ る。宗本らのモデルは、大森ら 4) によって建築構造物の構法順序に よる階層化を考慮したライフサイクル評価算定手法として確立され、 環境負荷低減の視点から $\mathrm{LCC} 、 \mathrm{LCCO}_{2}$ 、最終廃棄物量を評価尺度 とした多目的最適化を可能とするモデルが提案されている。また、
* 独立行政法人国立環境研究所 ポスドクフェロー・博士(工学)

(当時 東京大学大学院)

** 東京大学生産技術研究所 教授·博士 (工学)
Post-doc Fellow, National Institute for Environmental Studies, Dr. Eng.

Prof., Institute of Industrial Science, the University of Tokyo, Dr. Eng. 
陳ら 5)は、景観、温熱環境、経済性などの要因を考慮した樹木最適 配置に関する多目的最適化に取組み、屋外環境最適計画手法を開発 している。また、菅ら ${ }^{6)}$ は、室内環境設計過程の意思決定に多目的 遺伝的アルゴリズム手法を適用する設計支援手法を提案しており、 パレート最適解集合を求めることが意思決定のための支援情報を得 るためにも有効であることが示されている。以上のように、設計過 程に多目的最適化手法を適用した研究事例は多くみられ、その適用 有効性が示されているが、エネルギーシステム計画過程に多目的最 適化手法を適用した研究事例は少ない。

本研究では、 NCGA7) (Neighborhood Cultivation Genetic Algorithm)を採用した。GA は解空間に対して多点同時に探索でき るという特徴があるため、各目的関数に関してある程度良い值をと る個体を同時に持ちながら探索を進めることが可能である。直接的 にパレート解集合を探查できる利点がある一方、広域探索を行うた め、探索個体同士の空間距離が大きく、効果的な交叉ができない等 の問題が懸念される。NCGA はこの問題点を防ぐために開発された 多目的 GA (Multi-Objective Genetic Algorithm; MOGA)の一種で ある（図 1)。NCGA は、世代交代を重叔、最終世代に至るまでに 目的関数空間におけるパレート最適解集合を導く。

\section{3. エネルギーシステムの多目的最適化}

\section{1) 本研究における最適化の定義}

本研究は、グローバル最適解の導出よりも、設計計画に関わる意 思決定に資する解（ローカル最適解）の取得を主目的としている。 GA は “準最適解”を探査する手法であるため、得られた結果が真 の最適解 (グローバル最適解) であるかを確認するためには、GA の解に基づきシステム設計を行い、実システムを対象とした検証を 実施するか、全探查手法により得られた解と比較寸る必要があるが、 本研究目的に対しては、どちらも非現実的な検証方法といえる。よ って、本研究における “最適解”の記述は、“GA により得られた 準最適解”の意味で用い、以降の結果解析、および考察を進める。 最適化の拘束条件となる後述の需要データ、コストデータ、機器特 性データ、入力条件（設計変数、GA パラメータ）は、ユーザーが 適宜設定・変更でき、計算精度を確保できる枠組みを構築した。

\section{2) エネルギーシステム構成}

計算要素の簡潔にするため、使用燃料、設備機器、エネルギー需 要を構成要素とするエネルギーシステムのモデル化を行った。図 2 に資源投入から熱需要および電力需要までのエネルギーシステムの 相関図を示す。ここでの投入資源はガス、電気、太陽光の 3 種を考 えた。また需要側の CD、HD、WD、ED はそれぞれ冷熱、温熱、 給湯、電力需要を示す。供給可能な出力と使用燃料の種類は設備機 器ごとに特徵があり、各機器のエネルギーフローを矢印で示すこと とした。検討対象とする機器を表 1 に示す。ガスボイラ $(\mathrm{GB}) 、 ヒ$ ートポンプ (HP) は、各需要専用に設ける条件とした。最適化計算 の実施に際しては、エネルギー需要と各機器の容量が既知の值であ り、GA による機器能力組合せ選択と、全探査による各機器の出力 組合せにより、エネルギーフローの最適ルートが抽出され、システ ムに投入される一次エネルギー消費量の最小化が図られる。

\section{3）染色体情報の記述}

染色体情報は、出力別に対象機器を整理し、全 20 種類の遺伝子で

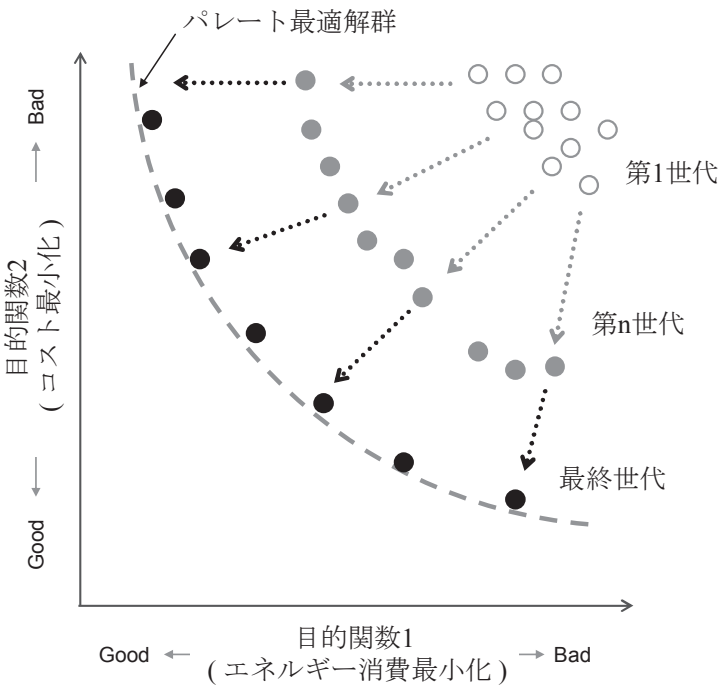

図 1 NCGA における解探査過程

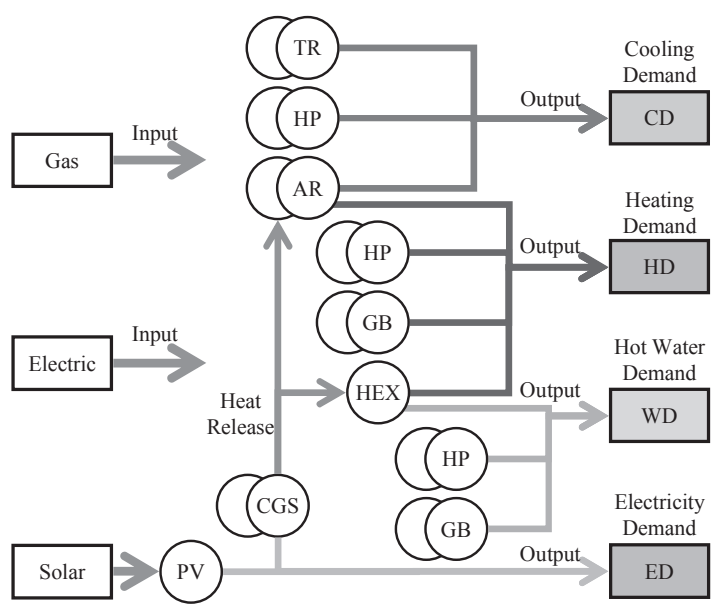

図 2 エネルギーシステム構成

表 1 設備機器リスト

\begin{tabular}{|c|c|c|c|c|c|c|c|c|c|}
\hline & & 定格COP & \multicolumn{2}{|c|}{ 入力 } & \multicolumn{4}{|c|}{ 出力 } \\
\hline & & & 冷 暖 & ガス & 電力 & 冷熱 & 温熱 & 給湯 & 電力 \\
\hline AR & 吸收式冷涷機 & {$[\mathrm{RT}]$} & $1.10 \quad 0$. & 0 & & 0 & 0 & & \\
\hline TR & ターボ冷凍機 & [RT ] & 2.50 & & 0 & 0 & & & \\
\hline EHP & 電気ヒートポンプ & [ HP ] & $2.04 \quad 1 . \mathrm{C}^{2} \mathrm{r}$ & & 0 & 0 & 0 & 0 & \\
\hline GB & ガスボイラ & [ kw ] & ---0.9 & 0 & & & 0 & 0 & \\
\hline CGS & コジェネレーション & {$[\mathrm{kw}]$} & $0.36^{* 1}$ & 0 & & 0 & 0 & 0 & 0 \\
\hline
\end{tabular}

*1 発電の定格 COP を記載。13A ガス熱量 $45 \mathrm{MJ} /\left(\mathrm{Nm}^{3} / \mathrm{h}\right)$ 電力の一次エネルギー原単位は $10.05 \mathrm{MJ} / \mathrm{kWh}$ とした。

\begin{tabular}{|c|c|c|c|c|c|c|c|c|c|c|c|c|}
\hline \multirow{3}{*}{$\begin{array}{c}\text { source } \\
\text { name }\end{array}$} & 1 & 2 & 3 & 4 & 5 & 6 & 7 & 8 & 9 & 10 & 11 & 12 \\
\hline & \multicolumn{7}{|c|}{ Cooling } & \multicolumn{5}{|c|}{ Heating } \\
\hline & TR1 & TR2 & $\mathrm{HPcl}$ & HPc2 & AR1 & AR2 & eneHP & GBh 1 & GBh2 & $\mathrm{HPh} 1$ & $\mathrm{HPh} 2$ & eneHP \\
\hline unit & RT & RT & $\mathrm{HP}$ & HP & RT & RT & $\mathrm{G} / \mathrm{E}$ & $\mathrm{kW}$ & $\mathrm{kW}$ & HP & HP & $\mathrm{G} / \mathrm{E}$ \\
\hline
\end{tabular}

\begin{tabular}{|c|c|c|c|c|c|c|c|}
\hline 13 & 14 & 15 & 16 & 17 & 18 & 19 & 20 \\
\hline \multicolumn{5}{|c|}{ Hot Water } & \multicolumn{3}{|c|}{ Electricity } \\
\hline GBw1 & GBw2 & HPwl & $\mathrm{HPw} 2$ & eneHP & CGS1 & CGS2 & PV \\
\hline $\mathrm{kW}$ & $\mathrm{kW}$ & HP & HP & $\mathrm{G} / \mathrm{E}$ & $\mathrm{kW}$ & $\mathrm{kW}$ & $\mathrm{m}^{2}$ \\
\hline
\end{tabular}

図 3 染色体情報 


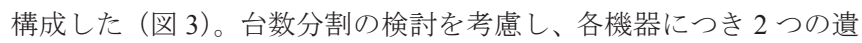
伝子を設定した。また、HP については使用燃料種がガス式、電気 式の 2 種を検討するため、燃料種類を決定する遺伝子を設定した （No.7, 12, 17)。太陽光パネル（PV）は設置面積を遺伝子として設 定した（No.20）。この染色体によってエネルギーシステムの構成を 表現し、各遺伝子を組み換えながら、様々な機器構成を作成し、運 用計算を行う。

\section{4) 目的関数}

本検討では目的関数として、運用にかかわる一次エネルギー消費 量 $O b j_{1}$ の最小化と、イニシャルコストおよびランニングコスト $O b j_{2}$ の最小化の 2 項目を設定した。これらの目的関数を一次式で統合し た結合目的関数 $O b j$ を最小化する重み係数法を採用した。結合目的 関数は、次の式 1 で定義される。

$O b j=W_{1} \frac{O b j_{1}}{S F_{1}}+W_{2} \frac{O b j_{2}}{S F_{2}}$

(式 1)

式 1 において $W_{1}$ と $W_{2}$ は重夕付け係数で、目的関数の重要度を差 別化するものである。計算条件としてユーザーが任意に設定できる 係数であるが、本報では、それぞれ 1 とし、2つの目的関数を等価 に扱った。また、 2 つの目的関数は、異なる次元の值であり、数值 の大きさも異なる。そこで、 2 つの目的関数の変動スケールのバラ ンスをとるために用いるスケールファクター $\left(S F_{1} 、 S F_{2}\right)$ を、Obj を $S F$ で除した值が $0.1 〜 1.0$ 程度の值になるよう設定した。

5) コストデータベース

必要な機器のコストデータについては、刊行物 8)9 に記載されてい る情報、およびメーカーへのヒアリング調査を通じて収集した。イ ニシャルコストには、機器単価 ${ }^{8)}$ 、搬入据付費 ${ }^{9)}$ および概算した配 管工事費が含まれる。エネルギーシステム構成は、機器容量で表現 された染色体情報の組合せによって記述される。染色体情報からイ ニシャルコストを算出するために、定格能力を係数とする近似式(式 2）を作成し、計算過程に組み込んだ。

$$
F_{c s t}=a x_{c a p a}^{2}+b x_{c a p a}+c
$$

機器価格、各機器の係数を表 $2 、 3$ に示す。また、ランニングコス トについては、運用計算から得られた各代表日の電力消費量、ガス 消費量に対し、エネルギー単価を乗じ、年間ランニングコストに概 算したものを用いた注 1 )。エネルギー単価は固定值とし、ガス 131.85 円 $/ \mathrm{m}^{3}(\mathrm{~N})$ 、商用電力 28.28 円 $/ \mathrm{kWh}$ を用いた。

\section{4. ケーススタディ}

本報では、開発した多目的最適化手法の妥当性および、設計過程 への適用有効性を検証するため、病院（所在地：東京、延床面積： $\left.6,000 \mathrm{~m}^{2}\right)$ についてケーススタディを行った。計算条件は以下の通 りである。

\section{1) 機器特性データ}

図 3 に部分負荷率と燃料消費効率の関係を示す。この機器能力曲 線は、メーカーカタログ值、および省エネ法に基づく CEC/AC 計算
プログラム「BECS/CEC/AC for Windows」10)の機器データベース の值を参照した。変数組合せ最適化問題に対し、染色体情報の選択、 交叉、突然変異を繰り返しながら最適な変数組み合わせを導く GA は、過去の計算履歴（生成個体）の結果を参照し、最適な組み合わ せを探査していくため、非線形問題であっても、解を導くことがで きる。これにより、機器の部分負荷特性を考慮した台数分割を検討 することができる。

\section{2) 需要データ}

需要データは、社団法人 空気調和・衛生工学会による「都市ガス によるコージェネレーション評価プログラム」（CASCADEIII）の デフォルトデータを参照した ${ }^{11)}$ 。計算過程で用いる值は、各季の代 表需要として 1 月、 4 月、 8 月を選出し、各月の代表日の 24 時間デ 一タを採用した。各代表日をそれぞれ冬季、中間季、夏季の代表日 とし、この需要に対する機器運用計算を行う。今回のケーススタデ イにおいて、病院施設の各種需要は、給湯、電力は各季ほぼ一定の 需要が存在するが、冷熱、温熱に関しては、季毎の需要差が大きい 特徵がある。CGS の機器容量はメーカーカタログ值を採用し、発電 効率は発電機端で $45.6 \%$ (LHV)、排熱効率 $31.4 \%$ （AR を熱源と

表 2 式 1 で用いる機器価格算出に関わる係数

\begin{tabular}{ccrrr}
\hline & & \multicolumn{1}{c}{$\mathrm{a}$} & \multicolumn{1}{c}{$\mathrm{b}$} & \multicolumn{1}{c}{$\mathrm{c}$} \\
\hline AR & $10^{3} \mathrm{yen} / \mathrm{RT}$ & 0.00002 & -0.0113 & 4.6348 \\
TR & $10^{3} \mathrm{yen} / \mathrm{RT}$ & 0.00002 & -0.0113 & 4.6348 \\
EHP & $10^{3} \mathrm{yen} / \mathrm{HP}$ & 0.4874 & -8.2716 & 110.51 \\
GB & $10^{3} \mathrm{yen} / \mathrm{kW}$ & 0.0000001 & -0.0002 & 0.2826 \\
CGS & $10^{3} \mathrm{yen} / \mathrm{RT}$ & 0.00002 & -0.0113 & 4.6348 \\
\hline
\end{tabular}

表 3 式 1 で用いる搬入据付費算出に関わる係数

\begin{tabular}{lllll}
\hline & & $\mathrm{a}$ & $\mathrm{b}$ & $\mathrm{c}$ \\
\hline AR & $10^{3} \mathrm{yen} / \mathrm{RT}$ & 0.0002 & -0.231 & 104.43 \\
TR & $10^{3} \mathrm{yen} / \mathrm{RT}$ & 0.0007 & -0.4464 & 112.76 \\
EHP & $10^{3} \mathrm{yen} / \mathrm{HP}$ & 0.0331 & -0.859 & 8.4988 \\
GB & $10^{3} \mathrm{yen} / \mathrm{kW}$ & 0.0001 & -0.0451 & 7.1259 \\
CGS & $10^{3} \mathrm{yen} / \mathrm{RT}$ & 0.0002 & -0.231 & 104.43 \\
\hline
\end{tabular}

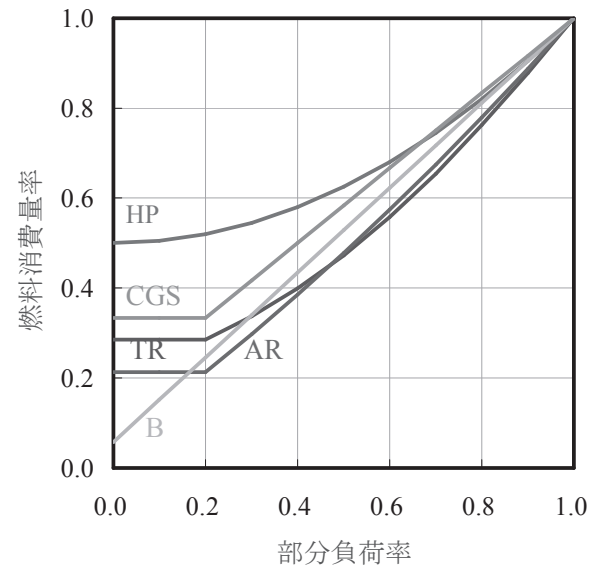

図 4 機器性能曲線 
して排熱を利用した場合の効率）の固定值とした ${ }^{12)}$ 。商用電力の発 電効率は、 $1,500^{\circ} \mathrm{C}$ 級コンバインドサイクル発電 $(\mathrm{MACC})$ の発電 端効率 $52.8 \%$ を採用した。これに送電損失率 $4.8 \%$ を考慮した受電 端効率 $50.4 \%$ を用いた ${ }^{13)}$

\section{3) GA 設計変数}

設計変数を表 4 に示す。計算過程の簡易化を考慮し、各機器のラ インナップは機器なしの 0 を含む 6 段階で染色体情報を作成した。 GB を除き、台数分割を検討するために 1 種類 2 台選択可能な染色 体構成とした。

表 4 設計変数

\begin{tabular}{|c|c|c|c|c|c|c|c|c|c|c|c|c|c|c|}
\hline \multicolumn{4}{|c|}{ 冷熱供給 } & \multicolumn{2}{|c|}{ 冷温供給 } & \multicolumn{3}{|c|}{ 温熱供給 } & \multicolumn{3}{|c|}{ 給湯供給 } & \multicolumn{3}{|c|}{ 電力供給 } \\
\hline $\begin{array}{c}\text { TR1 } \\
\text { [USRT] }\end{array}$ & $\begin{array}{c}\text { TR2 } \\
\text { [USRT] }\end{array}$ & $\begin{array}{l}\text { HP1 } \\
{\left[\begin{array}{ll}\mathrm{HP}\end{array}\right]}\end{array}$ & $\begin{array}{c}\text { HP2 } \\
{[\mathrm{HP}]}\end{array}$ & $\left.\begin{array}{l}\text { AR1 } \\
{[\text { USRT }]}\end{array}\right]$ & $\begin{array}{l}\text { AR2 } \\
\text { USRT ] }\end{array}$ & $\begin{array}{l}\text { GB1 } \\
{[\mathrm{kw}]}\end{array}$ & $\begin{array}{l}\text { HP1 } \\
{[\mathrm{HP}]}\end{array}$ & $\begin{array}{l}\mathrm{HP} 2 \\
{[\mathrm{HP}]}\end{array}$ & $\begin{array}{c}\text { GB1 } \\
{[\mathrm{kw}]}\end{array}$ & $\begin{array}{l}\text { HP1 } \\
{[\mathrm{HP}]}\end{array}$ & $\begin{array}{l}\text { HP2 } \\
{[\mathrm{HP}]}\end{array}$ & $\left.\begin{array}{l}\mathrm{CGS} 1 \\
{[\mathrm{kw}]}\end{array}\right]$ & \begin{tabular}{|l|}
$\mathrm{CGS} 2$ \\
{$[\mathrm{kw}]$}
\end{tabular} & $\begin{array}{l}\text { PV1 } \\
{\left[\mathrm{m}^{2}\right]}\end{array}$ \\
\hline 0 & 0 & 0 & 0 & 0 & 0 & 0 & 0 & 0 & 0 & 0 & 0 & 0 & 0 & 0 \\
\hline 125 & 125 & 10 & 10 & 30 & 30 & 58 & 10 & 10 & 58 & 10 & 10 & 115 & 115 & 50 \\
\hline 150 & 150 & 16 & 16 & 40 & 40 & 87 & 16 & 16 & 87 & 16 & 16 & 200 & 200 & 100 \\
\hline 200 & 200 & 20 & 20 & 50 & 50 & 116 & 20 & 20 & 116 & 20 & 20 & 230 & 230 & 150 \\
\hline 215 & 215 & 25 & 25 & 100 & 100 & 151 & 25 & 25 & 151 & 25 & 25 & 300 & 300 & 200 \\
\hline 230 & 230 & 32 & 32 & 120 & 120 & 186 & 32 & 32 & 186 & 32 & 32 & 350 & 350 & 500 \\
\hline
\end{tabular}

4) GA パラメータ

1 世代の検討個体数を 100 個体、検討世代数を 100 世代とし、 10,000 回の計算を行った。突然変異率は、筆者による既報 1)の結果 に基づき 0.05 とした。

\section{5) 排熱利用}

GAオペレータにより作成される機器構成候補にCGSが含まれる 場合、発電に伴う排熱が利用可能となる。排熱は、各季の代表日に おいて最大需要が最も大きい需要に対して供給されるものとし、そ の需要において利用しきれなかった余剩の排熱は活用されず放熱さ れるものとした。

\section{5. 計算結果}

\section{1) パレート最適解群の分布}

図 5 に、全検討個体 $(\bigcirc)$ と最終世代（100 世代目）の解の分布 （○）、その中から任意に抽出した計画案 10 候補 $\mathrm{A} \sim \mathrm{J} （ \diamond)$ の分 布を示す。横軸は各季代表日の一次エネルギー消費量合計、縦軸は イニシャルコストおよび各季代表日におけるランニングコストの合 計を示している。一次エネルギー消費と必要コストの間にはトレー ドオフの関係が見られた。エネルギーシステム計画者は、この解分 布から計画案を抽出し、比較検討の後、採用可能な現実解を絞るこ とができる。本報では、コストとエネルギー消費の関係を比較する ために、パレート最適解群の中から 10 候補を抽出したが、エネル ギーシステム計画額やエネルギー消費量削減目標值などを制約条件 とし、さらに解を絞った上で現実解を検討することも可能であると 考える。以下に、これらの機器構成および運用計画の比較を行った。

\section{2) 機器構成比較計画案}

10 候補における機器構成、および目的関数の結果を表 5 に示す。 計画案 A は計画案 J に対して約 $22 \%$ の一次エネルギー消費量削減 が見込めるが、約 7.8 倍のコストを要する結果となった。計画案 D、
E、 F は、一次エネルギー消費量がほぼ同じだが、選択された機器 構成（冷熱供給用 HP、給湯供給用 HP の容量）とその運用状況か らコストに差がみられた。本報では、その中でコストが最も小さい 計画案 $\mathrm{F}$ と、全体を通じてコスト最小である計画案 Jについて詳細 に考察する。計画案 $\mathrm{F}$ は計画案 $\mathrm{J}$ に対し、 $\mathrm{HP}$ や $\mathrm{GB}$ の能力が異な る他、TR (200USRT)、CGS $(350 \mathrm{kw}) 、 P V\left(500 \mathrm{~m}^{2}\right)$ が機器構成 に含まれる。これらの機器がコストおよび一次エネルギー消費量に 影響を与えていると考えられる。このように、計画候補案の分布は、 設計対象建物で考え得る機器構成候補群を定量的に比較検討するこ とができるため、設計過程において有効な成果となり得ると考える。

\section{3) 計画候補の運用計画}

運用計画については、全探查により最適解を導出しており、類似 した機器構成であっても、微細な能力差が運用計画に影響を与え、 図 1 のような解分布が形成された。計画案 F、Jについて、夏季に おける冷熱供給運用計画の計算結果を図 6,8 に、冬季における温 熱供給運用計画の計算結果を図 7,9 に示す。

夏季冷熱供給において、計画案 F では AR を介した CGS からの 排熱をべース負荷に、COP の高い TR を昼間の負荷に対応させる結 果を得た。冷熱需要を上回って供給されている部分については、機 器出力の計算条件に起因する過剩供給状況を示している。機器の運 用計算においては、出力 $0 \sim 100 \%$ の範囲を $10 \%$ 間隔で区切った 11 通りの離散值を設計変数としている。これを連続值、もしくは離散 間隔を細かくすることも可能であるが、計算負荷が極端に増大寸る ため、現実的ではないと考える。計画案 Jでは、CGS は機器構成に 含まれておらず、 2 台の $\mathrm{AR}$ を負荷状況に応じて運用する結果とな った。

冬季温熱供給については、計画案 F では CGS からの排熱利用と GB によるベース負荷対応、 2 台の AR による昼間ピーク負荷対応の 様子が確認された。計画案 J では、GB がベース負荷に対応し、2 台の $\mathrm{AR}$ が需要の大部分に対応する結果を得た。計画案ごとに最適 運用を実現する機器の稼働比率が異なることがわかる。本計算手法 を通じて、計画候補それぞれにおける最適な運用計画が導出され、 比較検討が可能である結果を得た。

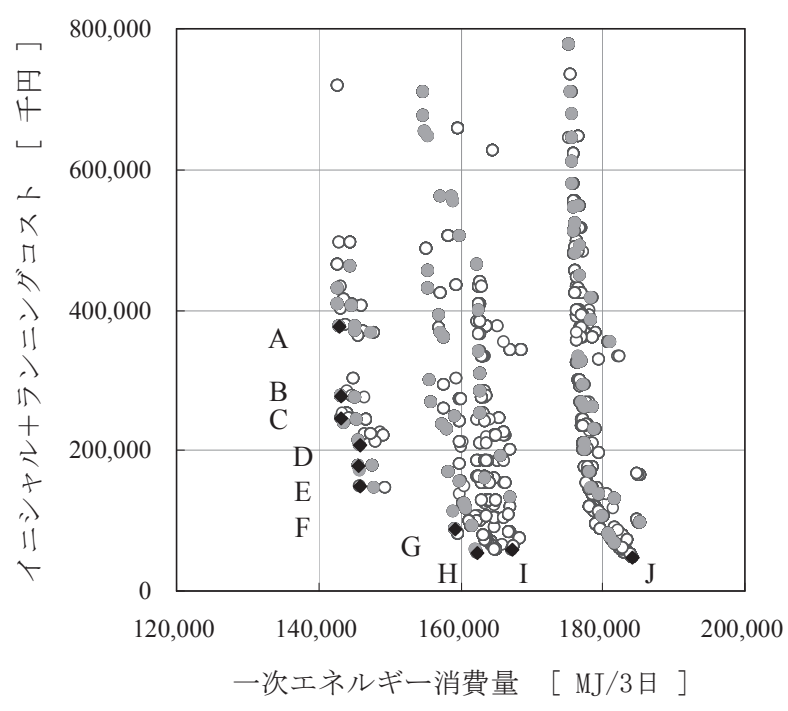

図 5 解分布 


\section{4) 計算時間}

今回のケーススタディにおける 10000 回の計算に対して要した 計算時間は、約 4 時間 30 分であった。計算に用いた計算機の CPU は、1.5GHz POWER5+プロセッサ（2GB）であり、現在の汎用計 算機が有する性能で十分計算可能である。以上より、本モデルは、
汎用計算機で利用でき、設計過程において導入可能な計算時間で解 を得ることができると考える。

\section{5) 適用範囲の限界}

本手法は図 2 に示すエネルギーシステム構成を原型とするエネル ギーシステムのみ検討対象とし、その枠組み内における解探査を行

表 5 計画案 10 候補における機器構成、および目的関数の結果

\begin{tabular}{|c|c|c|c|c|c|c|c|c|c|c|c|c|c|c|c|c|c|}
\hline & \multicolumn{4}{|c|}{ 冷熱供給 } & \multicolumn{2}{|c|}{ 冷温供給 } & \multicolumn{3}{|c|}{ 温熱供給 } & \multicolumn{3}{|c|}{ 給湯供給 } & \multicolumn{3}{|c|}{ 電力供給 } & \multicolumn{2}{|c|}{ 目的関数 } \\
\hline & $\begin{array}{c}\text { TR1 } \\
\text { [ USRT ] }\end{array}$ & $\begin{array}{c}\text { TR2 } \\
\text { [ USRT ] }\end{array}$ & $\begin{array}{l}\text { HP1 } \\
\text { [ HP ] }\end{array}$ & $\begin{array}{c}\mathrm{HP} 2 \\
{[\mathrm{HP}]}\end{array}$ & {$\left[\begin{array}{l}\text { AR1 } \\
\text { [ USRT ] }\end{array}\right.$} & $\begin{array}{c}\text { AR2 } \\
\text { [ USRT ] }\end{array}$ & $\begin{array}{l}\text { GB1 } \\
{[\mathrm{kw}]}\end{array}$ & $\begin{array}{l}\text { HP1 } \\
\text { [ HP ] }\end{array}$ & $\begin{array}{c}\mathrm{HP} 2 \\
{[\mathrm{HP}]}\end{array}$ & $\begin{array}{l}\text { GB1 } \\
{[\mathrm{kw}]}\end{array}$ & $\begin{array}{l}\text { HP1 } \\
{[\text { HP ] }}\end{array}$ & $\begin{array}{c}\mathrm{HP} 2 \\
{[\mathrm{HP}]}\end{array}$ & $\begin{array}{l}\text { CGS1 } \\
{[\mathrm{kw}]}\end{array}$ & $\begin{array}{l}\text { CGS2 } \\
{[\mathrm{kw}]}\end{array}$ & $\begin{array}{l}\text { PV1 } \\
{\left[\mathrm{m}^{2}\right]}\end{array}$ & $\begin{array}{c}\text { 一次エネルギー } \\
\text { [MJ/3days ] }\end{array}$ & $\begin{array}{l}\text { コスト } \\
{\left[10^{3} \text { yen }\right]}\end{array}$ \\
\hline A & 0 & 200 & 10 & 0 & 100 & 120 & 151 & 0 & 0 & 186 & 32 & 10 & 350 & 0 & 500 & 142,893 & 377,059 \\
\hline B & 0 & 200 & 16 & 10 & 100 & 120 & 151 & 0 & 0 & 186 & 25 & 16 & 350 & 0 & 500 & 143,187 & 276,904 \\
\hline $\mathrm{C}$ & 0 & 200 & 0 & 10 & 100 & 120 & 151 & 0 & 0 & 186 & 25 & 16 & 350 & 0 & 500 & 143,282 & 245,953 \\
\hline D & 0 & 200 & 10 & 16 & 100 & 120 & 151 & 0 & 0 & 186 & 20 & 0 & 350 & 0 & 500 & 145,665 & 178,900 \\
\hline E & 0 & 200 & 10 & 0 & 100 & 120 & 151 & 0 & 0 & 186 & 20 & 0 & 350 & 0 & 500 & 145,776 & 147,952 \\
\hline$\underline{F}$ & $\underline{0}$ & $\underline{200}$ & $\underline{0}$ & $\underline{0}$ & $\underline{100}$ & $\underline{120}$ & $\underline{151}$ & $\underline{0}$ & $\underline{0}$ & $\underline{186}$ & $\underline{25}$ & $\underline{0}$ & $\underline{350}$ & $\underline{0}$ & $\underline{500}$ & $\underline{145,803}$ & $\underline{207,623}$ \\
\hline G & 0 & 0 & 0 & 10 & 100 & 120 & 151 & 0 & 0 & 186 & 10 & 10 & 350 & 0 & 500 & 159,133 & 88,304 \\
\hline $\mathrm{H}$ & 0 & 0 & 0 & 10 & 100 & 120 & 151 & 0 & 0 & 186 & 10 & 10 & 0 & 350 & 0 & 162,441 & 54,830 \\
\hline I & 215 & 0 & 0 & 0 & 100 & 120 & 87 & 0 & 0 & 186 & 10 & 10 & 0 & 0 & 0 & 167,234 & 59,212 \\
\hline$\underline{J}$ & $\underline{0}$ & $\underline{0}$ & $\underline{0}$ & $\underline{0}$ & $\underline{100}$ & 120 & $\underline{87}$ & $\underline{0}$ & $\underline{0}$ & $\underline{186}$ & $\underline{10}$ & $\underline{10}$ & $\underline{0}$ & $\underline{0}$ & $\underline{0}$ & 184,208 & $\underline{47,908}$ \\
\hline
\end{tabular}

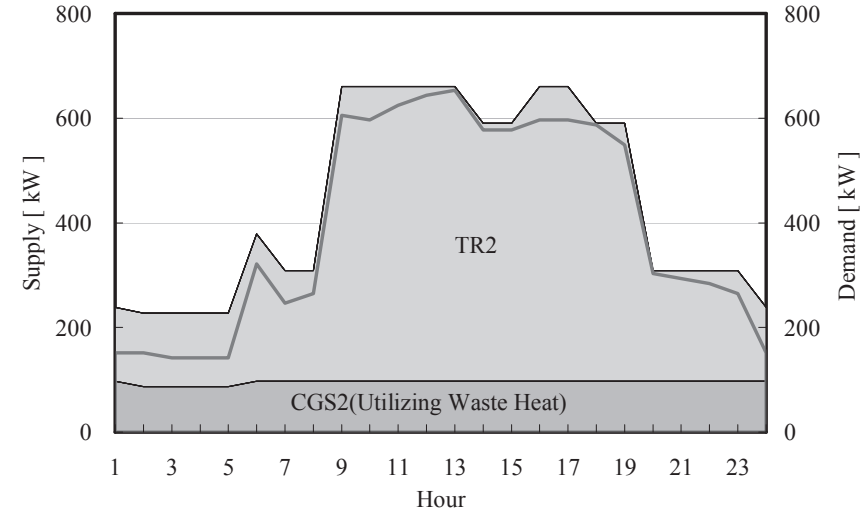

図 6 計画案 $\mathrm{F}$ における夏季冷熱供給運用計画

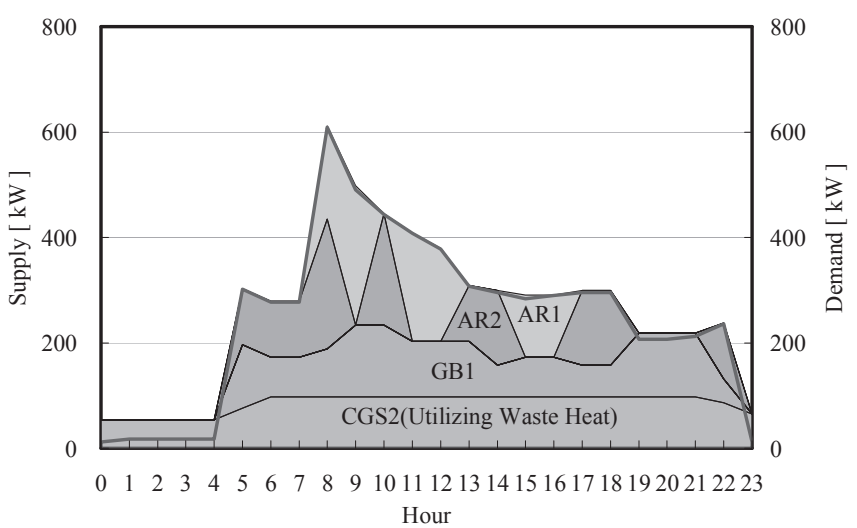

図 7 計画案 $\mathrm{F}$ における冬季温熱供給運用計画

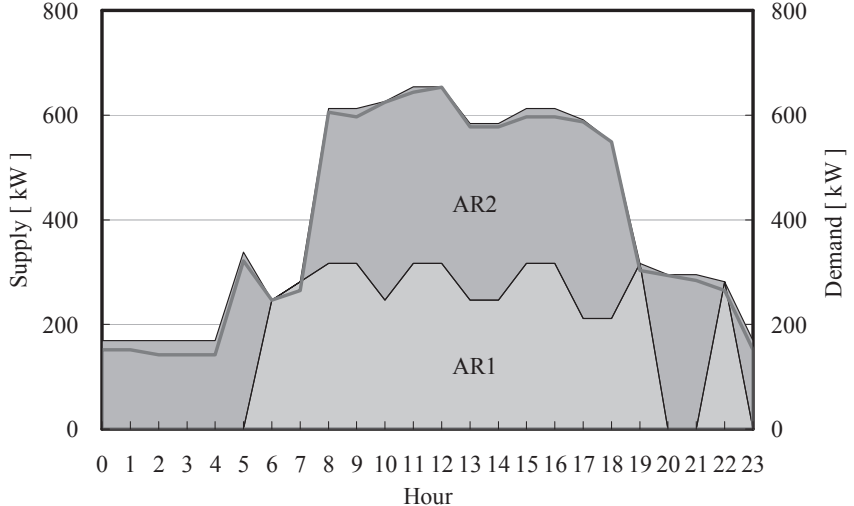

図 8 計画案 Jにおける夏季冷熱供給運用計画

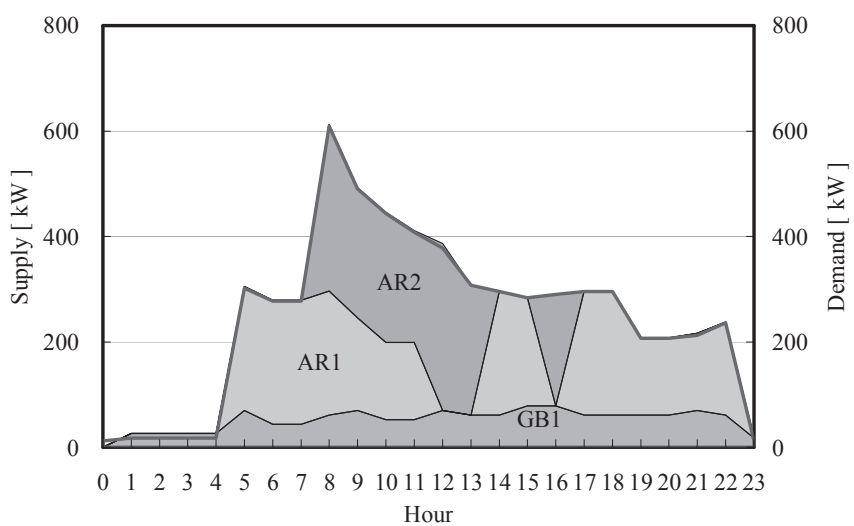

図 9 計画案 Jにおける冬季温熱供給運用計画 
うものである。どのようなシステムの構造を考案するか、すなわち どの機器を組み合わせ、どのようにつないだ系が性能と効率が良い かという最適化問題については、本手法の適用外となる。また、本 手法は、時刻ごとの静的な解析を行う計算過程であるため、蓄熱・ 蓄電など、動的な最適化計算は行っていない。現実状況を反映する ため、今後の開発課題である。さらに、エネルギー収支を計算する 時、熱エネルギーも電力エネルギーも $[\mathrm{kW}]$ で検討している。このた め、低温度差エネルギーの利用など、温度の高低を考慮したエネル ギー利用は検討できない。これについても今度の開発課題とする。

\section{6.まとめ}

1）本報では、多目的 GA を用い、複数の目的関数に対して最適解群 を導くエネルギーシステム計画手法を作成し、ケーススタディを 通じてその有効性を検証した。

2）ケーススタディから得られた解分布は、計画額や設計条件など、 意思決定プロセスにおいて考慮される検討要素から計画案の候 補となる最適解群を提供し得る結果を得た。

3）本計算手法を通じて、計画候補それぞれにおける最適な運用計画 が導出され、比較検討が可能である結果を得た。

4）本モデルは、汎用計算機で利用でき、設計過程において導入可能 な計算時間で解を得ることができる結果を得た。

\section{注}

注 1）ランニングコスト算出方法を以下に示す。

ガスコスト[ 円/3 代表日 ]

$=$ ガス消費量 $\left[\mathrm{MJ} / 3\right.$ 代表时 $\div 45\left[\right.$ 円 $\left./ \mathrm{m}^{3}(\mathrm{~N})\right] \times 131.85\left[\right.$ 円 $\left./ \mathrm{m}^{3}(\mathrm{~N})\right]$

電カコスト $[$ 円/3 代表日 ]

=商用電力消費量 $[\mathrm{MJ} / 3$ 代表日 $] \div 9.97[\mathrm{MJ} / \mathrm{kWh}] \times 28.28[\mathrm{円} / \mathrm{kWh}]$

年間ランニングコスト [ 円/年 ]

$=($ ガスコスト +電力コスト $)[円 / 3$ 代表日 $] \times 30$ [日 $/$ 月 $] \times 4$ [月/季 $]$

\section{参考文献}

1）加用現空，大岡龍三 : 遺伝的アルゴリズムを用いた分散エネルギーシステ ム最適計画手法の開発 予測精度に及ぼす GA パラメータの影響検討と 分散エネルギーシステムの効果の確認, 日本建築学会環境系論文集, 第 74 巻, 第 641 号, pp.869-876、2009.7

2）弥田俊男, 宗本順三, 吉田哲, 高野俊吾 : 独立住宅モデルの建材選択に伴 $5 \mathrm{LCC}, \mathrm{LCCO} \_2$, 最終廃棄物量低隇の多目的問題：住宅建材の選択シ ステムへの GA 適用の研究, 日本建築学会計画系論文集 第 524 号, pp.77-84, 1999.10

3) 宗本順三, 鉾井修一, 張本和芳, 吉田哲, 高野俊吾: 独立住宅モデルの建材 選択に伴う LCC, LCCO_2, 最終廃棄物量低隇の多目的問題：その 2 GA を用いた「標準問題の建物モデル」への住宅建材・工法選択システム, 日本建築学会計画系論文集 第 551 号, pp.85-92, 2002.1

4) 大森博司, 野田賢: 遺伝的アルゴリズムによる建築構造物のライフサイク ルデザインに関する研究, 日本建築学会構造系論文集第 601 号, pp.181-188, 2006.3

5）陳宏, 大岡龍三, 加藤信介 : 多目的遺伝的アルゴリズム(MOGA)を用いた 屋外環境設計ための樹木の最適配置に関する研究, 空気調和・衛生工学会 学術講演会講演論文集, pp.1091-1094, 2004.9

6) 菅健太郎, 加藤信介, 樋山恭助 : 多目的最適化におけるパレート最適解集 合の構造解析 一多目的遺伝的アルゴリズムを用いた建物外装空問題一 の適用一, 日本建築学会環境系論文集, 第 73 巻, 第 625 号, pp.283-289, 2008.3

7）渡辺真也, 広安知之, 三木光範 : 近傍培養型遺伝的アルゴリズムによる多 目的最適化，情報処理学会論文誌 Vol.43, pp.183-198, 2002.11
8）財団法人 建設物価調查会：月刊建設物価, 2007.7

9）全日出版社：機械設備工事積算実務マニュアル(平成 19 年度版)

10）財団法人 建築環境・省エネルギー機構 ; 空気調和設備の省エネルギー 計算プログラム BECS/CEC/AC for Windows Ver3.2 操作マニュアル, 2001.6

11）社団法人 空気調和・衛生工学会 : 都市ガスによるコージェネレーショ ン評価プログラムーCASCADE一, 丸善, 2003.12

12）清嶺地誠：バルチラ社製新型ガスエンジンの導入, 日本ガスタービン学 会誌, Vol.35, No.2, pp.81-84, 2007.3

13）柳父悟，西川尚男：エネルギー変換工学 地球温暖化の終焉に向けて，東 京電機大学出版局, pp.83-85, 2004.3

（2009年 9 月 7 日原稿受理，2010年 4 月 20 日採用決定） 